\title{
The Role of Private Security Companies in the Provision of Security to Corporate Organizations in Sabon Gari Local Government, Kaduna State, Nigeria
}

\author{
Abubakar Mohammed Bashir
}

\begin{abstract}
Security of lives and properties of people used to be the sole responsibilities of the State, but currently, the worldwide and growing trend in providing security services through private companies is clear in Nigeria, Sabon Gari Local Government to be specific. Corporate organizations in this local government rely on these private companies for security. This study therefore, investigates the contributions of private security companies in security provision for corporate organizations in the study area, and confidence the organizations have for them. A qualitative method of data collection was used. Purposive sampling using snowball was used. An in-depth interview was conducted to six informants from both the corporate organizations and the security services. Finding shows that the private security companies play important role in the provision of security and the corporate organizations have confidence on them. The study recommends that government should encourage and improve the activities of private security companies in Nigeria.

Index Terms:- Corporate organization, crime, Kaduna State, private security.
\end{abstract}

\section{INTRODUCTION}

Globally, the security of lives and property has been a matter of serious concern. Wherever people live together as a group, security problems become inevitable. In every society, developed or developing, simple or complex, security of lives and property has always been of paramount importance. In an attempt to reduce the rate or prevent crime and ensure safety and security in the society, different measures in both modern and traditional societies were taken. For instance, the installation of surveillance cameras in public places, man guarding an access control, guards patrolling, vigilante group, secret cults etc.

Private security companies are also alternative measures formed to prevent crime and bring safety to the society. Some names given to Private security sector/ industry are Private Military Security Companies (PMSCs), Private Security Organization (PSOs), corporate security and Private Security Companies (PSCs). The differences in name are sometimes a matter of nomenclature or based on the modus operandi of particular company. However, their activities easily overlap. Various scholars give different definitions of the private security sector. organizations perceived to be offering traditional military

Revised Manuscript Received on July 10, 2019.

Abubakar Mohammed Bashir, College of Law, Government, and
Private Military Security Companies (PMSCs) as private International Studies, Universiti Utara Malaysia.

services, the majority offer a more protective service while Private Security Companies (PSCs) more protective for their client. The security companies are defined as companies that specialize in providing security and protection of personnel and property, including humanitarian and industrial assets. Corporate security as a specialized form of private security providing services to private sector companies and sometimes to public sector organizations [1].

Worldwide, privatization of the security industry is experiencing a period of rapid growth, and when it is properly regulated, can improve the security of a country. The increasing demand for private security companies around the globe reflects serious shortcomings in the public security organizations to control the menace of crime and insecurity. In some countries this has led to the increase in private security companies to be more than the public security organizations. For instance, in the UK, Poland, the USA, and Turkey, the number of private security personnel is nearly twice as high as that of the public police force. In France and Germany, the private sector is about two thirds of the size of the state police. Most of these countries except UK permit the carrying of firearms by private security guards. The increasing prevalence of non-state actors in national and international security rests in particular on four factors: number, scope, expertise and resources. The number and scope of international regimes and organizations have grown significantly since the end of the Cold War, which had created obstacles to cooperation. New international regimes include among others the Chemical Weapons Convention; the Comprehensive Nuclear Test-Ban Treaty; and the Convention on the Prohibition of the Use, Stockpiling, Production and Transfer of Anti-Personnel Mines and their Destruction [7].

Across the globe, crime and insecurity remain the largest threat to humanity, northwest and Nigeria in general is by no means exceptional. Crime and insecurity are threats that not only endanger profitability, but may also lead to the collapse of any particular economic system. In Nigeria for instance, prior to the advent of private security companies (PSCs,) there exists the tradition of employing security guards as a watchman by individuals or organizations. An organized and registered private security company that is Nigeria Investment and Security Company (NISCO) began in 1965. As insecurity and privatization of public properties continue

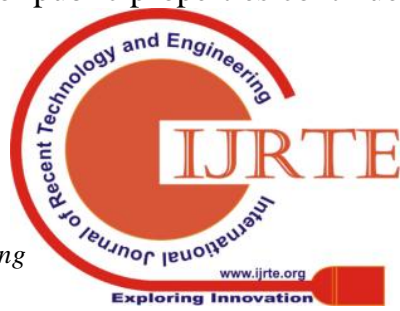




\section{THE ROLE OF PRIVATE SECURITY COMPANIES IN THE PROVISION OF SECURITY TO CORPORATE ORGANIZATIONS IN SABON GARI LOCAL GOVERNMENT, KADUNA STATE, NIGERIA}

to increase in Nigeria, particularly from 1999 at the beginning of this democratic dispensation, the demand for private security companies increased. The country has witnessed the proliferation of PSCs and informal security organizations. This increase in the demand may be attributed to the worrisome state of insecurity in the country and the inability of the Nigeria Police Force to curtail the situation. Private security personnel can be seen guarding businesses, banks, communities, private and public organizations in major cities of the country. It is difficult to give the accurate size of the private security companies that operate in the country because some of them are unlicensed and unregistered. However, the number of private security organizations (PSOs) was estimated to be between 1,500 and 2000 and employing in excess of 100, 000 people in Nigeria. This estimate, therefore, shows that, private security companies have become a major part of the Nigerian economy [2].

According to [4], the business of private security is growing and has gone through a silent revolution. This rapid growth and expansion of the private security companies in Nigeria cannot be ignored or go unnoticed. Fear of crime seems to be a very plausible explanation for the growth in the private security companies. People are no longer content to leave security issues to public security organizations in Nigeria. This informed the decision taken by hunters and civilians to combat terrorism in north eastern part of the country. In Nigeria today, security responsibilities are shared with different organizations like ethnic militias, vigilante groups and private security companies. Although this happened as a result of the fear of insecurity, it is an aberration to section 214 (1) of the 1999 constitution of the Federal Republic of the Nigeria, which stipulates that only the Nigeria police shall be the only police force in Nigeria. Communities of highly placed people, private and public organizations in Nigeria, northwest in particular have become increasingly reliant on private security companies. This is unfortunate because the mode of operation of private security companies that is supposed to provide safety for all look like that of the public security organizations. It is not just companies that need additional security for private companies today, private individuals rich or poor, local and public authorities, and the government also needs private security services because of the high rate of insecurity in Nigeria. This paper will therefore, concentrate on the function and the acceptability of the private security companies to the corporate organization.

\section{METHODOLOGY}

Sabon Gari as a case study for this paper is one of the 23 local government areas of Kaduna State. The local government is bordered to Zaria, Kudan, Igabi and Giwa local government areas. It's a host of many private organization and train station. Research design is a usual qualitative technique use to discover a limited system indepth [3]. The case study research design is usually conducted in a place limited in term of place, time, or some physical boundaries. The data collection method was qualitative using in-depth inter-views. This study sourced and used primary and secondary data. One - on - one indepth interview as a significant tool for data collection was used. Interview assist the researcher to realise the task set out to achieve, such as explaining the phenomenon, or measuring them, identifying the specific problem of the research question [5]. For these reasons, semi structured indepth interview was designed and administered to security personnel and mangers of the organizations. The interview schedule was designed for the key informants to describe the roles and acceptability of private security companies in Sabon Gari Local government area.

\section{RESULTS AND DISCUSSION}

Majority of the informants interviewed agreed that the security of corporate organizations in Sabon Gari local government is shouldered on the private security companies. For instance, some of the informants interviewed have these say, "the private security personnel here are trying they are responsible in guiding the customers and the protection of the environment, however, they are always challenged by lack of equipment", (inf. 5). Another informant corroborated the above argument as follows:

The security and organization of activities in this bank is the responsibility of our firm (private security company). We arrange the activities, inspect and prevent any doubtful act.

Our men are all over the banking premises, some with uniform while some on private wears (Inf. 3).

Corroborating the above submission, another informant has this to say "the private security companies have been very active the monitoring of services and rapid response to any eventuality" inf. 6 . This shows that the private security plays good role in the provision of security in the study area. The above finding was corroborated by [8] which found the roles of private security company as an organization with the ability to provide a proximate capacity for violence that is they provide defensive security services, equipment, and training to (mostly) multinational corporations, businesses, humanitarian agencies, and individuals. This shows that private companies in the study area a playing the needed roles.

Another informant who is a manager in one of the corporate organisations argued as follows:

The private security guards are doing their best, in fact, I feel protected with them. They are always here all the time rendering very important services to our organization. Yes, some of them are train and give us very good advice on the security of this organization. From the report they write

daily you get to understand they are very good in the provision of security. However, the only problem they are face with is the lack of arms to face criminals, (Inf. 1 and 6).

The study shows that very good number of the security companies operating in Sabon Gari local government of Kaduna State, have competent and trust worthy security guards. For instance, an in-formant has this to say:

One of the cardinal points of our operation is professionalism, our men are well trained by retired military officers under the supervision of civil defense. They are train on general security and administration. However, you find some of the organization that recruit members that are 
not train probably because of cheap labor. But truth to God a good number of them display their expertise. If you are any crime in the bank now may be its armed robbers (Inf. 5).

Despite the poor salary paid to private security companies in Nigeria, the personnel are less corrupt compared to security operatives in the public service like the police. This assertion was corroborated by one of the informants interviewed as follows:

The private security personnel are trust worthy, I have never suspected them in any way. Let me tell you, I do send some of them to my personal house and they have betrayed me. Their attention is always on duty post. I cannot say there are no bad ones, but the fact remain that they are not as corrupt as the Nigerian police who are better paid. They are discipline, because they really beg for favor. What they need is for the government to approve those using arms for proper protection like is done in South Africa where private security companies are sued for protection and conflict resolution (Inf. 4).

The above argument was corroborated by another informant, his submission are as follows:

There is trust on those recruited as staff of private security companies. In fact, this is my 10th years working in different banks, I have never experience where any of them is found wanting. There are many complain on the part of the police officers. The only problem with this private security is that the government refused to allow them use $\operatorname{arm}(\operatorname{Inf} .7)$.

The above submission was also supported by another informant, his arguments are as follows:

The private security here provides the best in security services, I am very confident when they are around, and that makes me concentrate fully in my work. I never heard about any criminal incident in my office, they are all well trained staff, however, they need to have sophisticated weapons to improve their services (Inf. 10).

On the contrary, the private security companies are perceived by some informants as not performing any good role in the provision of security in the study area. For instance, another informant has this to say:

The private security companies are not playing any role in crime prevention, criminals are not here because of the police around. How do you expect private security to be effective while they are not allowed to hold weapon? They are only relevant because banks use them as cheap labor that keep surveillance around the banking hall. They are trust worthy, the problem I just one, they don't have weapon for protection (Inf. 8 and 9).

This shows that private security companies can only be effective if they are permitted to use arms in the prevention of crime. Further-more, findings show that the security guards are perceived to be trustworthy in the study area.

\section{CONCLUSION}

Private security companies serve as alternatives to public security outfits, and again provide employment to good number of people in Nigeria, Kaduna State in particular. Findings from this paper show that the private security companies are effective, however they are constrained with lack of legislation that allows them to use arms for crime prevention. Based on the findings, the paper recommends that government should make law that will allow the private security personnel to use arms in the prevention of crime.

\section{REFERENCES}

1. C. Meerts, "Corporate security-Private justice?(Un) settling employer-employee troubles," Security Journal, 26(3), 2013, pp. 264-279.

2. R. Abrahamsen, and M. C. Williams, The globalisation of private security: Country report: Nigeria. 2015, Available: http://users.aber.ac.uk/rbh/privatesecurity/country\%20reportnigeria.pdf.

3. J. W. Creswell, and V. L. C. Plano, Understanding Research: A Consumer Guide. Massachusetts: Merrill/Pearson Educational, 2015.

4. E. Hollemans, Private security: A disturbing peace of mind. 2005, Available: https://mg.co.za/article/2005-05-05-privatesecurity-a-disturbing-peace-of-mind.

5. U. Sekaran, and R. Bougie, Research Methods for Business. New Jersey: John Wiley and Sons, 2013.

6. F. Shreier, and M. Caparini, Privatizing security: Law, Practice and Governance of Private Military and Security Companies. Geneva: Democratic Control of Armed Forces (DCAF), 2005.

7. Stockholm International Peace Research Institute, SIPRI Yearbook 2011: Armaments, Disarmament and international Security. England: Oxford University Press, 2011.

8. M. Small, "Privatisation of security and military functions and the demise of the modern nation-state in Africa," ACCORD Occasional Paper, 2006(2), 2006, pp. 1-44. 